\title{
Behind the Disastrous Spiral of Terrorist Brutality
}

James D Liou

Yu Da University, Miao-Li, Taiwan

*Corresponding author: James D. Liou, Yuda University, Miao-Li, Taiwan; Tel: +886-37-651188, E-mail: dian@ydu.edu.tw

Rec date: Mar 01 2016; Acc date: Mar 14, 2016; Pub date: Mar 19, 2016

Copyright: (c) 2016 Liou JD. This is an open-access article distributed under the terms of the Creative Commons Attribution License, which permits unrestricted use, distribution, and reproduction in any medium, provided the original author and source are credited.

\begin{abstract}
The existing terrorism and counter-terrorism imply that some form of interaction between the actions of terrorist organization and defending state is bound to arise. This paper attempts to initiate a systematic description for analyzing the dynamic behavior of terrorist organization and defending state by causal loops in order to explain the present relevant situation and to initiate a possibility of rapprochement in the future.
\end{abstract}

Keywords: Terrorism; Causal loops

\section{Integrated Perspective of Terrorism}

Terrorism is different from all other types of traditional armed conflict faced in the past, because of its different nature and the character of its participants [1]. The term terrorism has been used frequently in mass media communications but has not yet been consensually defined. Some critics have suggested the word is too often simply applied to whatever violent groups the United States and its allies opposes, pointing to the often-cited claim that "one's terrorist is another's freedom fighter," or some other less pejorative terms. However, In general, terrorism implies "the threat or actual use of force or violence to attain a political goal through fear, coercion, or intimidation" [2], "criminal acts intended or calculated to provoke a state of terror" [3], and "premeditated politically motivated violence perpetrated against noncombatant targets by subnational groups or clandestine agents" [4]. Terrorism is then a form of asymmetrical warfare by non-state actors against innocent noncombatant civilians. No wonder Donna Jo Napoli, a Swarthmore College linguistics professor, looks to the word's roots for what she sees a clear and unambiguous meaning and argue that "When you say terrorism you do mean 'trafficking in terror'; anything that could terrorize people [5].

Krieger and Meierrieks [6] provide an overview on the empirical literature on the determinants of terrorism and find that terrorism is rooted in political repression, state failure, ethnic conflict and foreign policy behavior [7]. Although there are many groups may be considered as terrorist, we narrow its scope to Muslim extremists as subject for facilitating discussion.

\section{Dynamic Behavior on Both Sides}

Despite via simplified to study relative issue, human systems are far more complex than physical systems and therefore representing terrorist behavior in a model is unique challenge.. However, strides on the concept of feedback or circular causality have been made in this area to understand the dynamic behavior of a system. Developing causal loop diagram is a typical approach to depict feedback for intricate system and to show factors and their causal linkages. Such mapping can therefore elucidate potential mechanisms and dynamic pathways on which counter-terrorism intervention strategies should focus.
A causal loop diagrams represent the feedback structure of systems through arrows and polarities [8]. On each diagram, the arrows represent influences by one factor on another. A "+" sign indicates a positive correlation between the events, while a "-" sign indicates a negative correlation. Depending on the polarities of the causal links present, each feedback loop can generate one of two types of effects-a snowball effect, where a change in state generates bigger or more changes, or a balancing effect, where a change in state generates action to absorb the change.

In addition to the sophisticated pattern of relations, one of the features that make the behavior of complex systems so difficult to predict, is the presence of delays. It takes time to make a population to overcome the sentiments of hatred, frustration, resentment or fear resulting from years of violence, oppression or deprivation, in an ethnic conflict. It takes time for public diplomacy to work in antiterrorism policies, sometimes much more than expected [9]. In the causal loop diagram as Figure 1 shown, a double bar (II) on the connection between two variables (factors) indicates a delay.

Although the cause of terrorism is diverse and there is no single factor appears to incur terrorists to commit violent incidents, however, one of origin for these tragic events should be aroused from the US and its European vassals intended to predominate resources in the Middle East. One of the world's richest oil and gas deposits are located in Muslim lands. It can't be denied that resources of the wealth in Muslim regions are used by the West. While the Western industrial societies have developed and live in welfare, the Middle East societies are in poor and backward [10]. Therefore, the conflict between terrorism and counterterrorism is a series of competition for resource control in Muslim lands. The rectangular box noted in the causal loop diagram is the level variable of interest that is governed by creation and loss rates which in turn influenced by various factors. The contest for resource, power, and benefits control in the Middle East may be illustrated (as Figure 1) in a rectangular box by growth and decline of both forces. 
Page 2 of 3

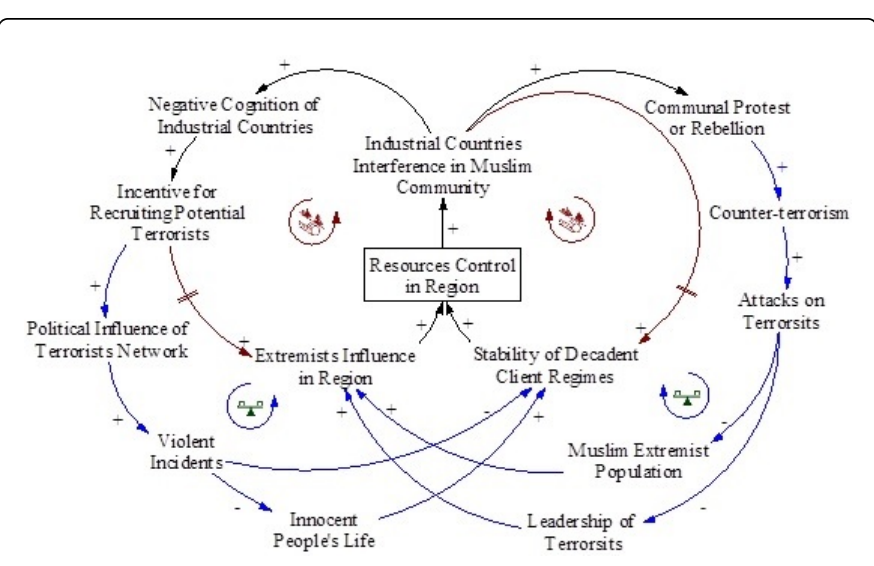

Figure 1: The pattern of current international affairs on terrorism issue.

The extremists target the wider population of the group that they regard as representative of the crimes committed against them. This in turn sparks retaliation [11]. The intense tragedy of this is that the violence in Middle East is transported to the streets of Western cities where it can easily become prevalent [12]. Figure1 shows that policy objective in attacking Muslim extremists may curb the number of terrorist population and destroy their bluster. The effect of repression can also hit the leadership of terrorists, in a way to reduce their capacity of planning and implementing effective actions against the Western governments. Certainly this would be an effective and popular political move to reduce the number of terrorist attacks in the short term. Unfortunately those repressive actions have an influence on exacerbating the collective cohesion of Muslim extremists, which in turn props up the 'potential for mobilization', which further strengthens the terrorist activities [9].

The US policy of using Muslim extremists started with arming them in Afghanistan under Osama Ben Laden, a CIA operative, to overthrow a relatively secular government allied with the then USSR. That worked well initially, except for the ultimate outcome: an antiAmerican Muslim extremist Afghan regime. Then, faced with a Yugoslavia that, unlike the rest of Eastern Europe after the break-up of the USSR, refused to fall prey to Western private capital, the US provoked ethnic conflict to break up the nation, partly by backing Islamic groups. The legacy of that policy is an uncontrollable Islamgangster state in Kosovo. Later, the US and its allies tried to use sectarian conflict to retain control over Iraq after the US invasion and occupation did not replace the independent, secular regime with a passive, pliant one, but the result was an Iraqi regime allied to Iran, an enemy of the US. Subsequent uses of extremists in attempting regime change in Libya and Syria have ended in disastrous loss of US control of the situation in both countries. Finally, the result of decades of US support for Israel's extermination of Palestinians has been the Islamization of the Palestinian resistance. The whole process has embroiled the region in conflict and weakened the decadent despotisms that are still obedient to the US [13]. Now, a more horrible group, the Islamic State of Iraq and al-Sham (ISIS), which also calls itself the Islamic State, has supplanted al Qaeda as the jihadist threat of greatest concern. Extinguishing the beacon of hatred embodied in terrorist groups has might excite for anti-terrorism globally, but the attitudes of ISIS, al-Qaida, Boko Haram and all the other sinister gangs in the world will live on.
In other words, such a punitive approach would only have the longterm effect of further exacerbating the sense of grievance amongst the Muslim extremists and result in a case of positive feedback: an activity intended to restrain the rebellion ends up propping it up. Both outer rings of Fig. 1 explains two balancing loops that counteract the attempt of terrorism and counterterrorism, which represent consequences that were unexpected and counterproductive from the viewpoint of the US and its allies.

If ISIS or other radical Islam continues to terrorize the world, what should we do? As the great scientist Albert Einstein said, "The world will not be destroyed by those who do evil, but by those who watch them without doing anything." Right now, as a global village, we should be seriously reflecting upon the exploitative role we have taken in the world. We should ask how such hatred, embodied in ISIS has come to exist. We should turn our energy not against terror itself (since this only feeds into the agenda of the terrorists), but against the global powers that bred the attack [14]. Freytag et al. [7], suggests that governments ought to counter terrorism not exclusively by relying on the 'stick' (i.e. hard measures), even though related policy means (e.g. investments in the security apparatus) may also pay off. Instead, using soft measures (the 'carrot') may be helpful in the fight against terrorism. Improvements in Muslim regions' socio-economic situation (e.g., policies that foster growth, investment and economic participation) may therefore make terrorism less likely. Long-term solutions involve building a resilient and tolerant community. In such means that focus on development may help to marginalize terrorism by making terrorist less grievances and then decreasing violent activity, but not to wipe it out. This is like an extremely difficult when countries have multicultural populations where the wounds of sectarian violence are still fresh. However, if this balance cycle is prevalent, then counterterrorism will have chance to be successful; otherwise, it will have the effect of fuelling violence.

\section{Conclusion}

Despite terrorism is a complex phenomenon when it is analyzed, dynamic behavior of its causal linkages is often disregarded. We propose a systemic thinking to illustrate relationships between potential terrorism threat and counter-terrorism activities for practical decision making.

If human intelligence is not sufficient to choke off terrorism, the circulation among antiterrorism and terrorism will be endless, just as the causal loops this paper illustrated. Based on the observations stated in this article, we have good grounds for thinking that whether terrorism or counterterrorism will present opportunities and challenges for humanity-respect development.

\section{References}

1. Gross E (2011) Fighting Terrorism with One Hand Tied Behind the Back: Delineating the Normative Framework for Conducting the Struggle against Terrorism within a Democratic Paradigm. Wisconsin International Law Journal 29:1-33.

2. Alexander Y, Valton D, Wilkinson P (1979) Terrorism: Theory and practice. Boulder, CO: Westview Press 4.

3. United Nations (1999) United Nations General Assembly Resolution 51/210. Measures to Eliminate International Terrorism.

4. Witschel G (2004) The legacy of September 11. Terrorism and the international business environment: The security-business nexus 9-24.

5. http://abcnews.go.com/US/story?id=92340\&page $=1$ 
Page 3 of 3

6. Krieger T, Meierrieks D (2011) What causes terrorism? Public Choice 147:3-27

7. Freytag A, Kruger JJ, Meierrieks D, Schneider F (2011) The origins of terrorism: Cross-country estimates of socio-economic determinants of terrorism. European Journal of Political Economy 27:5-16.

8. Sterman JD (2000) Business Dynamics: Systems Thinking and Modeling for a Complex World: The McGraw-Hill Companies, USA.

9. Bartolucci V, Gallo G (2015) Terrorism, System Thinking and Critical Discourse Analysis 32:15-27.

10. Ozer AC (2016) Terrorism in the World. J Socialomics 5:140.
11. http://linchpin.org/site/?p=1199

12. For instance, three Americans and a British man subdued armed gunman Ayoub El-Khazzani on a high-speed train between Amsterdam and Paris on Aug. 21 of 2015, another reminder of Europe's susceptibility to attacks by individual radical Islamists apparently working alone.

13. North K (2014) Folk Tales, Foreign Policy, and the Value of Systems Thinking

14. Kington D (2015) Writing on The Wall: The Paris attacks should fuel a fight against Western imperialism, not refugees, University Wire, USA. 